\title{
THE IMPLEMENTATION OF INDONESIA'S CHILD FRIENDLY SCHOOL POLICY BASED ON ENVIRONMENT IN THE COASTAL TOURIST AREA OF GUNUNGKIDUL, INDONESIA
}

\author{
Mami HAJAROH* \\ Yogyakarta State University, Educational Policy Study Program, Faculty Of Education, Indonesia, e-mail: mami_hajaroh@uny.ac.id \\ Rukiyati RUKIYATI \\ Yogyakarta State University, Faculty of Education, Indonesia, e-mail: rukiyati@uny.ac.id \\ L. Andriani PURWASTUTI \\ Yogyakarta State University, Educational Policy Study Program, Faculty Of Education, Indonesia, e-mail: lusilaap@uny.ac.id \\ Bambang SAPTONO \\ Universitas Negeri Yogyakarta, Primary Education Study program, Faculty of Education, Indonesia, e-mail: saptono@uny.ac.id
}

\begin{abstract}
Citation: Hajaroh, M., Rukiyati, R., Purwastuti, A.L., \& Saptono, B. (2020). THE IMPLEMENTATION OF INDONESIA'S CHILD FRIENDLY SCHOOL POLICY BASED ON ENVIRONMENT IN THE COASTAL TOURIST AREA OF GUNUNGKIDUL, INDONESIA. GeoJournal of Tourism and Geosites, 31(3), 1010-1018. https://doi.org/10.30892/gtg.31312-535
\end{abstract}

\begin{abstract}
Child-friendly school policy in the tourism area need to be developed as an effort to overcome the social economic problems faced by children in line with the development of tourism. This study aimed at implementing the policy of Child Friendly School Policy in the coastal tourism area at district of Gunungkidul, Indonesia, where children's development is identified as being at great risk. This policy was originally contained in government regulation of women empowerment and child protection number 8 in 2014 and was then formulated into education policy. Qualitative descriptive data were collected by a process of focus group discussion and observation. The results showed the implementation of child-friendly school policy requires school regulations with contextual policies and programs. Parents and communities need to synergic cooperation in implementing the child-friendly school policy. The child-friendly school policy was formulated through: 1) mobilizing some stakeholders i.e. parents, community leaders, teachers, principals and school superintendents and education departments that have a significant role in the development of child-friendly school policies; 2) considering some aspects, i.e. the characteristics of the coastal tourist area, the aspect of natural environmental conditions, socio-cultural society, political culture and power, cultural, economic, employment and labour, and the information and communication technology, and; 3) implementing school-based management which required the participation of the school community in the education of the children. It could be concluded that parents and the community have important role in developing child friendly school.
\end{abstract}

Key words: policy education; child friendly school; coastal tourism area; environment; primary School.

\section{INTRODUCTION}

Creating a school environment as a place for students to learn safely and comfortably becomes a necessity. With a safe, comfortable and healthy school environment will make children feel at home school and study in peace. In addition, children will also grow, develop and participate in education process fairly without violent intimidation. In Indonesia, the effort to create such environment is a mandate of Act No. 23 year 2002 on the child protection (KPAI, 2013). Article 3 of the Act states that a child protection aims to ensure the fulfillment of children's rights in order to live, grow, develop, and participate optimally in accordance with human dignity, as well as protection from violence and discrimination, in order to create qualified, noble and prosperous Indonesian children. Whereas Article 4 of the child protection states that every child has the right to live, grow, develop and participate fairly in accordance with human dignity, as well as protection from violence and discrimination. Children's rights as stated in article 3 and 4 of Act No.23 / 2002 on child protection has not been optimally fulfilled (KPAI, 2013). There is still high level of violence against children in Indonesia. Data from the Indonesian Child Protection Commission on Setyawan (2015) said violence against children is increasing every year i.e. in 2011 there are 2178 cases, in 2012 there are 3512 cases, in 2013 there are 4311 cases, in 2014 there are 5066 cases. This fact has to be encountered by children in their family circle and at school. Schools are supposed to be a safe and comfortable place for children to learn but are often found not to meet those needs. Results of research by Plan International and the International Center for Research on Women (ICRW) found 84\% of children in Indonesia have experienced violence at school. This number is higher than the trend in Asia of 70\% (Setyawan, 2015). Fast (2016) showed that violence in schools is an important issue, therefore being important in the global agenda and the need for direct responsibility in educational policies with legitimate authorities.

Child Friendly School is a Unicef policy that emerged in 2006. The child-friendly school framework is a framework based on the principles of child rights (Miske, 2010). Child rights principles set out in the Convention on the Rights of the Child (1990) and international human rights instruments and declarations, including the Declaration on Education for All. In part 2 of Article 42 page 12 CRC says: "The State agrees to make the principles and provisions in this convention Widely acknowledged Among adults and children in an Appropriate and practical way." In other words, the obligation to fulfill children's rights are assigned to us, adults, to ensure that all children are cared for, protected and supported to be able to develop fully the physical, emotional, social, and intellectual equality and integrity aspects. Framework for kindergarten include: Child-Friendly Schools are child-centered; They are inclusive; They are gender-equitable and celebrate all cultural backgrounds and languages; They are effective - that is, in Child-Friendly Schools children are learning and being educated; Child-Friendly Schools are protective, safe, healthy environments; and They are characterized by democratic participation.

The purpose of child-friendly schools is to create school environments that provide children's rights as set out in the Convention on the Rights of the Child. It is the obligation of adults, parents and teachers to create child friendly school that the children are able to get their full

\footnotetext{
${ }^{*}$ Corresponding author
} 
rights. UNICEF's (2006) Child Friendly School Manual in chapter 3 stated the main purposes of the plan of child-friendly schools are: Attract students increase access. Improve attendance rates; Improve retention and completion rates; Improve learning environment; Provide safe inclusive, welcoming environments for all students; Provide enabling learning environment, including accomodating children with physical and mental/learning diabilities; Build a sense of community within the school (institutional ethos); Involve parents and the community support and participation; Cultivate harmony between the school and the community; and Harmonize buildings, school grounds and environment as children interact with them.

Child Friendly School approach is also based on the Convention on the Rights of the Child (Clair et al., 2012). CFS standard is a comprehensive, the standard-level system of CFS is more than just academic achievement or fulfillment of all aspects of the child rights. Convention on the Rights of the Child (CRC) states that all girls and boys in the world are entitled to the right to live; the right to develop (including the right to be educated); the right to get protection from all forms of violence, neglec and exploitation; and the right to participate in matters that affect their lives and prepare children to take on increasing roles of responsibility at the time.

(UNICEF, 2009) also conduct research on the development of child-friendly schools in many countries, including Thailand, the Philippines, Nigeria, China and Chambodia. In developing CFS they take the base on the key principles that CFS can be interpreted and applied in various contexts. They develop CFS standards in provinces and districts suitable to their characteristics. This development approach in addition to being a model that is more coherent, predicable and logical, it also increases the democratic process of dialogue and consultation in interpreting key principles and CFS standards setting.

In Indonesia the development of CFS policy of Unicef has been done with the advent of Minister of State for Women's Empowerment and Child Protection of the Republic of Indonesia Number 8 of 2014 on child-friendly schools that are used as a reference for stakeholders in developing CFS. The principles of child-friendly schools in Indonesia as stated in the Regulation of the Minister of Women's Empowerment number 8 of 2014 (Republic Indonesia, 2014) are: 1) Non-discrimination, guarantee every child the opportunity to enjoy the rights of children to get education without discrimination on the basis of disability, gender, ethnicity, religion, and parents' background; 2) The best interests of the child are always a primary consideration in all decisions and actions taken by the management and the education providers with regard to students; 3) Life, survival and development which are to create an environment that respects the dignity of the child and to ensure holistic and integrated development of each child; 4) Respect for the views of children which includes respect for the right of children to express views in all matters affecting the child in the school environment; and 5) Good management that ensures transparency, accountability, participation, transparency of information and rule of law in the education unit.

Child-friendly school policy in Indonesia stated aims to: Fullfill, guarantee and protect the rights of children through the school environment; Being a guide for districts / cities in developing child-friendly schools; Meet one of the indicators for districts / cities eligible for children. The components developed in the child-friendly school include: Child Friendly School Policy; Implementation of the curriculum; Education and Educational personnel trained about children's rights; Child Friendly School's Infrastructures; Child Participation; and Parents participation, Public Agencies, Business World, other stakeholders and alumni (Republic Indonesia, 2014).

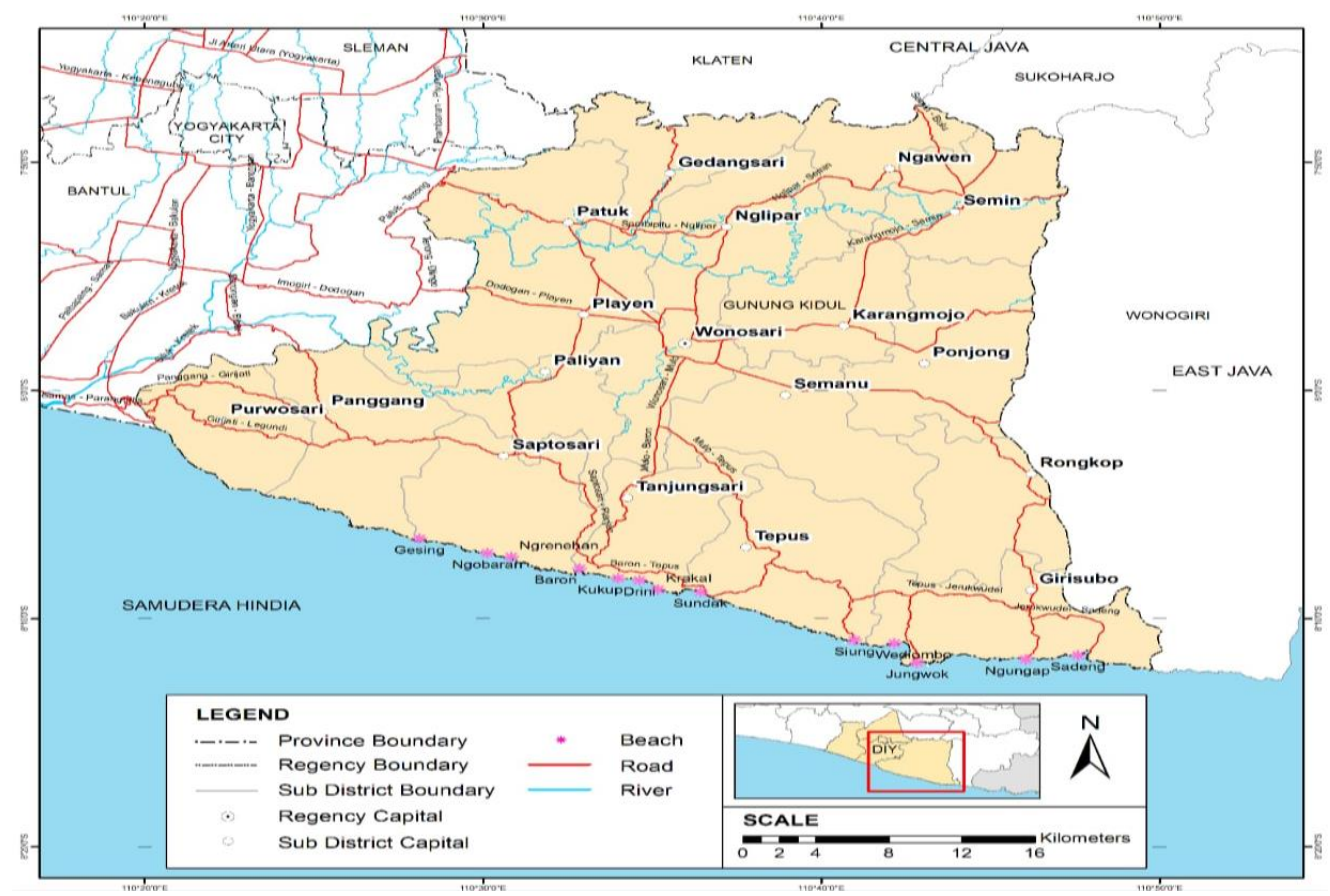

Figure 1. Coastal Tourist area Tanjungsari, district of Gunungkidul, Yogyakarta, Indonesia

Schools in the child-friendly school policy process contributes as implementer of policy. How schools are implementing important policies to examine as Vincent et al. (2016) research in his research article focusing on national and institutional policy enforcement challenges children's friendships held in 3 schools in London. Young and Lewis (2015: 3-17) analyzes the results of research on the implementation of policy with the title Educational Policy Implementation Revisited. Each school has a social, culture and education context that differ one another that each school needs to develop policies so that the policies and programs are relevant and suitable for the needs of the school so that the quality of education is getting better. The policy at the school level are closely related to regional autonomy, schoolbased management (SBM) or Community-Based Management (CBM). Schools and communities are two important institutions in education. When schools applying SBM, how many percent the role of the community in the provision of education in schools? How many percent of the school activities and programs organized by the public the communities? When the role between school and communities are equal, then $50 \%$ of the communities contributes in providing education. Has this happened in schools? Society can influence what happens in the educational institution, or educational institution can actually be transferred to the community. Therefore, to create a child-friendly school 
starts with developing and formulating policies at the school level which means schools (principals and teachers), education department and the community should work together to formulate the problem and seek solution for the problem in the form of school policy. Bøyum (2014: 856-870) states that in developing Education policy depends on the assumption of justice in Education. Regardless of justice, the policy will be in the dark and will only reproduce social inequality through education whether the policy is made explicit or unstructured. Without looking at justice, one will be in the dark about what to do about the reproduction of social inequality through Education.

Indonesia with a wide variety of culture, ethnic, race and geographical location requires the interpretation of the development of childfriendly school policy at the local level such as province, region/city and specific areas such as agricultural areas, coastal areas, urban areas, can implement this policy. Coastal tourist area in Tanjungsari, district of Gunungkidul, Yogyakarta is an area that still lacks attention in the development of child-friendly schools. With the development of nature tourism in the area of Gunungkidul, children need to get more serious attention in their lives at school and at home so that they can grow and develop in accordance with its development.

To improve the quality of education in this region, it is important to implement the policy as in the regulation number 8-year 2004. As stated by Carrington et al. (2017) to improve the quality of education requires a clear policy; However, in many developing countries, there has been a history of lending policies rather than developing culture information-based policy. By developing school policies based on environments, the policy in line with the local culture but still in line with national policies frame will be found. Policy statement developed by the shool govern the behavior of schools' members to create child-friendly schools. Morrison (1996) states that primary school-primary schools are required to have a written policy statement governing behavior. Policies aimed at some of the issues that are understood as an important key in the policies that school policy is comprehensive (whole-school) and a proactive and positive policy.

This paper presents how schools implement the national policy through the development of child-friendly schools through policy development based on school environment at the coastal region of Gunungkidul.

\section{METHODOLOGY}

This research is a research about the child-friendly school policy implementation in primary school at coastal tourist district of Gunungkidul. The object of the research is national policy implementation process the unit level of education (school). Te kind of the research is developmental research to show and develop child friendly schools in coastal tourims areas of Yogyakarta Special Region used 3 step Define, Design and Developt by Thiagarajan and Semmel (1974). The study was carried out in elementary schools in the tourist coastal area of Gunungkidul district in Tanjungsari district involving 3 elementary schools, namely SD Kemadang, SD Ngestiharjo and SD Rejosari. The techniques of data collection are interviews, focus group discussions, and documents. Data were analyzed by qualitatively descriptive, consist of understanding the meaning of data analysis; analysis when collecting data; data reduction; data presentation; drawing conclusions and verification (Miles \& Huberman, 1992). The research process is carried out by defining, designing and developing. The scheme of research is depicted in Figure 2 below:

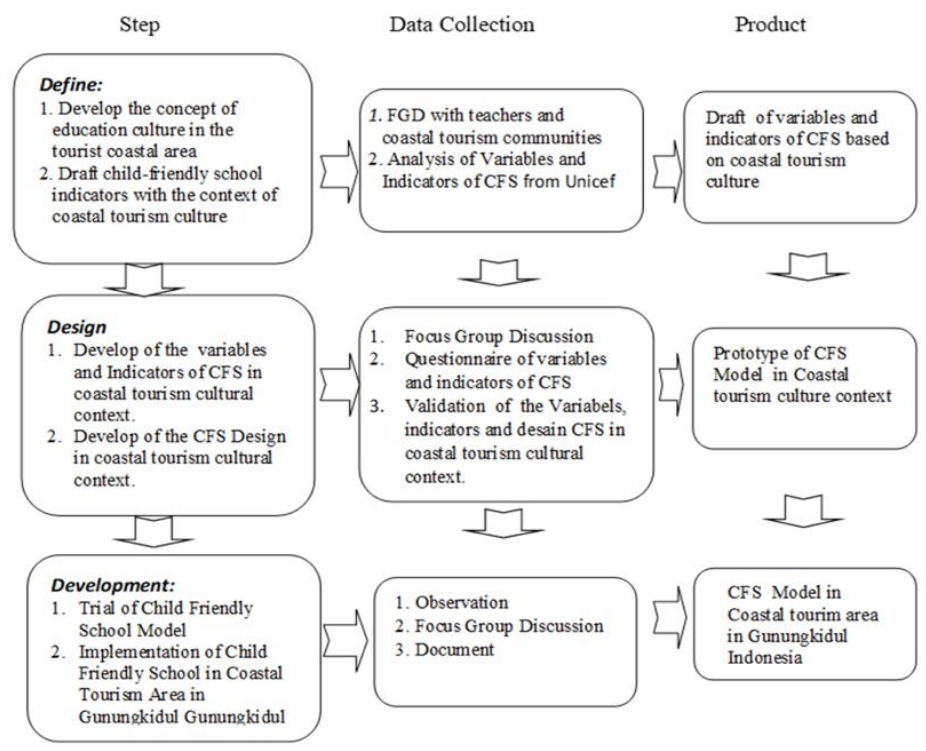

Figure 2. The Scheme of Research (adopted from Thiagarajan \& Semmel, 1974)

\section{RESULT AND DISCUSSIONS}

Development of coastal tourism has a major impact on the livelihoods of local people (Çakir et al., 2018). Therefore, Çakir recommends to improving the livelihoods of local people and achieving environmental, social and economic sustainable results with tourism livelihoods, recommending policies that support and encourage local communities. In Tuzunkan's research (Tuzunkan, 2018: 103-111) explained that sustainable tourism development requires high-quality and educated workforce. His research also states that between tourism businesses and the government need to work together. The provision of a qualified and educated workforce to develop tourism in Gunungkidul is sought from young people in the local community. This effort was carried out as early as possible since they took elementary education. Developing child-friendly schools has an interest in educating young people to become qualified and educated workforce while reducing the negative impact of tourism development itself. Implementation of child-friendly school policy a stated through three stages namely: 1 . The interpretation of policy by developing and formulating policies at the school level; 2 . The policy decisions; 3 . The application of the policy in the school. In this case schools have autonomy to develop policies.

\section{The Interpretation of Policy}

Interpretation of the policy of national policy into school policy is the first activity undertaken in policy implementation. The national policy is open so that each district and school is able to develop policies based on school environment. In this case schools have autonomy to develop policies. Van der Sluis et al. (2017: 303-329) states that well-developed school autonomy can help improve the quality of education. 
School policy based on environments as well as in the school-based management requires the school to do the analysis in developing and formulating policies and school programs based on school socio-cultural context. School policies and programs are a translation of the above policy. This means that school policies and programs are a set of relationships and practices, and especially relationships between school actors, allowing policies to become part of school practice, perception and development. Perryman et al. (2017: 745-756) describes several ways in which teachers work for themselves and others, and make themselves subject to policy and understand the process of translation, practice and technique as ethical, contemporary constitutions and contingent professionalism. In formulating the policy of child-friendly schools in coastal areas involves actors namely the head of education department of Gunungkidul, principals, teachers, parents, guardians, school committees, community leaders and education experts from Yogyakarta State University. These policy actors are initiating the issues about policy, arranging alternative policies, formulating policies and making policy decisions and implementing them in school.

Developing policies in primary schools in coastal areas is important as for school policy will make the school safer, more comfortable and in harmony with the surrounding environment. School policy has strategic role in creating child-friendly schools. Results of research conducted in England by Samara and Smith (2008) in primary school about school policies, interventions, and the frequency of bullying found that most of the schools changed after having a policy on bullying as part of a broad policy on behavior and discipline, schools have anti-bullying policies. This indicates that a school policy provides significant changes in the behavior and discipline of children. In an effort to create child-friendly schools to develop policies based on the school environment is a must. Findings from Cross et al. (2011) show the policies and whole-of-school programs involving students with different social contexts led to a reduction of them experiencing bullying and increase the chance of them telling someone if they are bullied. This study reinforces the importance of policy in changing the understanding and the behavior of the school members. Friendly school policies aim to change the behavior of the school members and the surrounding areas sitematically.

Child-friendly schools in coastal tourism communities are specific. Because of his region has the following characteristics: first, the natural environment is an area prone to earthquakes and tsunamis that can occur unpredictably. The changing the coastal area into a tourism area brings slowly and significantly impact be positive and negative social and economic changes in the community. Second, the economic cultural conditions and employment opportunities. Transfer of land functions gives risen to new jobs that have an im pact on involving children into workers. Third, the condition of social culture. The arrival of domestic and foreign tourists with th eir culture has an impact on changes in the values, ways of thinking, patterns of behavior and lifestyles that are positive or negative. Fourth, the condition of political culture and power. Coastal areas that are undergoing changes in anticipating negative impacts on children's education require policies from the government, social organizations and political organizations. The components of power and political ownership need to be involved in the development of schools and child-friendly education. Fifth, the condition of the communication and information technology environment. The rapid development of information and communication technology is also experienced by children in coastal areas. This gives children opportunities to access information by children is often negative information that is harmful and even damaging mentally and morally. Therefore, in developing child-friendly school policies it is important to pay attention to various characteristics of the coastal tourism area in Gunungkidul. Therefore, the flow of policy development and school program within the framework of the implementation of child-friendly school can be seen in the following Figure 3.

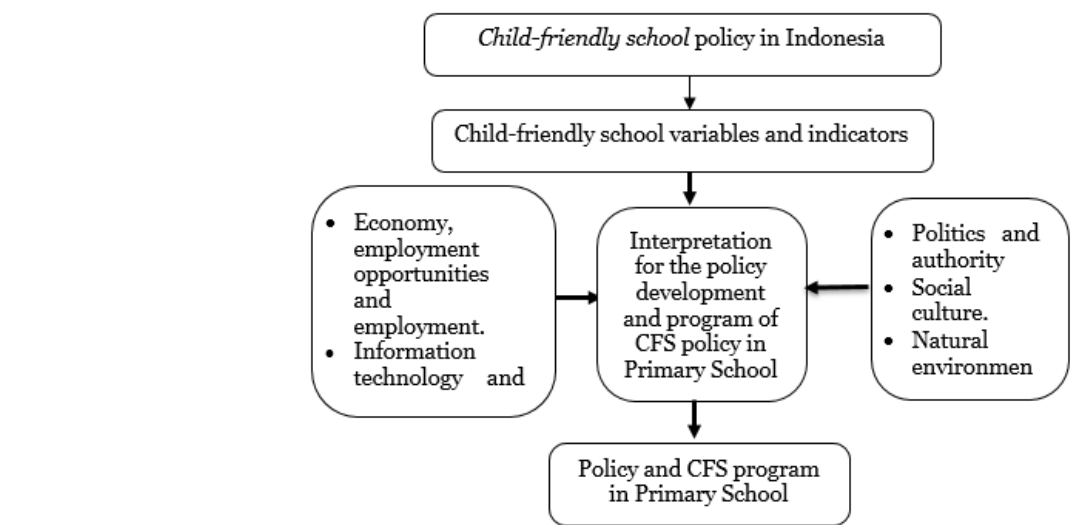

Figure 3. The flowchart of the policy development within the framework of Child-friendly Schools policy interpretation

There are four steps of the process of policy formulation at the Child Friendly School in education unit level in the coastal tourist district, namely: policy analysis, formulation, implementation, and evaluation of policies. These four steps are the procedures of the policy process undertaken by schools in implementing school-based management. Child-friendly school policy development in the coastal tourist area of Gunungkidul through several stages in the procedure as the policy process: Policy analysis, Policy formulation of child-friendly schools in coastal tourist district of Gunungkidul, and Implementation of policies and programs of child-friendly school.

\section{Policy Analysis}

Child-friendly school policy analysis begins with analyzing the issues for formulating policies and concludes with policy issues. Formulating appropriate policy is the most important step in a series of policy formulation, as there are more errors in the process of policy making than in the formulation of the solution making. Errors in formulating a problem despite getting the right solution still can not resolve the real problem in the community. In the last 5 years the coastal area of Gunungkidul has changed from agricultural areas into tourist areas that have an impact on the socio-economic changes of society. Socio-economic changes can be positive or negative. The negative impact of tourism often perceived by the school. The negative impact related to the growth of children is their immoral acts committed by the tourists in deserted places around the coast. The children primary school saw and even recorded the tourist negative act. Beside that they are happier to be seller or help their mother to sell things on the beach during the school day. Even primary school children are happier to be a parking attendant than to attent additional classes. These are the basic problems in education in the coastal tourist area.

Domestic and foreign tourist arrivals with their culture impact on changes in values, ways of thinking, behavior patterns and lifestyle both positive and negative. The development of information and communication technologies is very fast that is also experienced by children in coastal areas, giving them the opportunity to access information. It is just the information that is accessible to children are often negative that harm and even ruin the children's mental and moral. Another problem is the alignment of policies at school and at home. Policies and 
programs which are set in the school is not in line with what the parents conduct at home. Smartphones have negative impact and influence their behavior easily. Schools have forbidden children to use smatphone but at home they can use it freely. The change of the culture of farming and fishing communities towards the management of sea tourist attraction has brought significant changes in terms of increased income and socio-economic status of the communities. Improved economic status has no positive impact on education. As delivered by the teachers, many parents who are economically well off but do not have a desire and a high appreciation for the education of their children. The coastal area is experiencing a change in anticipating negative impact on children's education requires a policy from the government, community organizations, political organizations and schools to develop policies and implement child-friendly schools.

\section{Policy formulation of child-friendly schools and policy decision}

The school policy is a concrete direction made by the school to create a child-friendly school. At the operational level at school, policy is a guideline, the blueprint to be used as a reference of activity. All school activities refer to the school's policy. Policy is not a concept, but the policy is no longer formulatd but it is the formula itself. In formulating policies and programs, schools in this area interpret the policy from KPPPA No. 8/2014 and then formulate appropriate programs and activities of the socio-cultural context of the school.

Regulation which was reduced to Legislation is common. Tuytens and Devos (2014: 155-174) stated policy makers often make policy public. This puts the responsibility for developing and implementing the policy to principals and teachers as local implementing agencies in schools. Child-friendly schools context specified in Gunungkidul needs to develop the operational concept of child-friendly schools in the form of programs and activities. Conceptual policies must be operationalized, made by competents, people who understand the coastal areas, have knowledge about child development and education. The policy that can not be operationalized by involving stakeholders will be a dictator policy. In versa, good policy should be a systematic process.

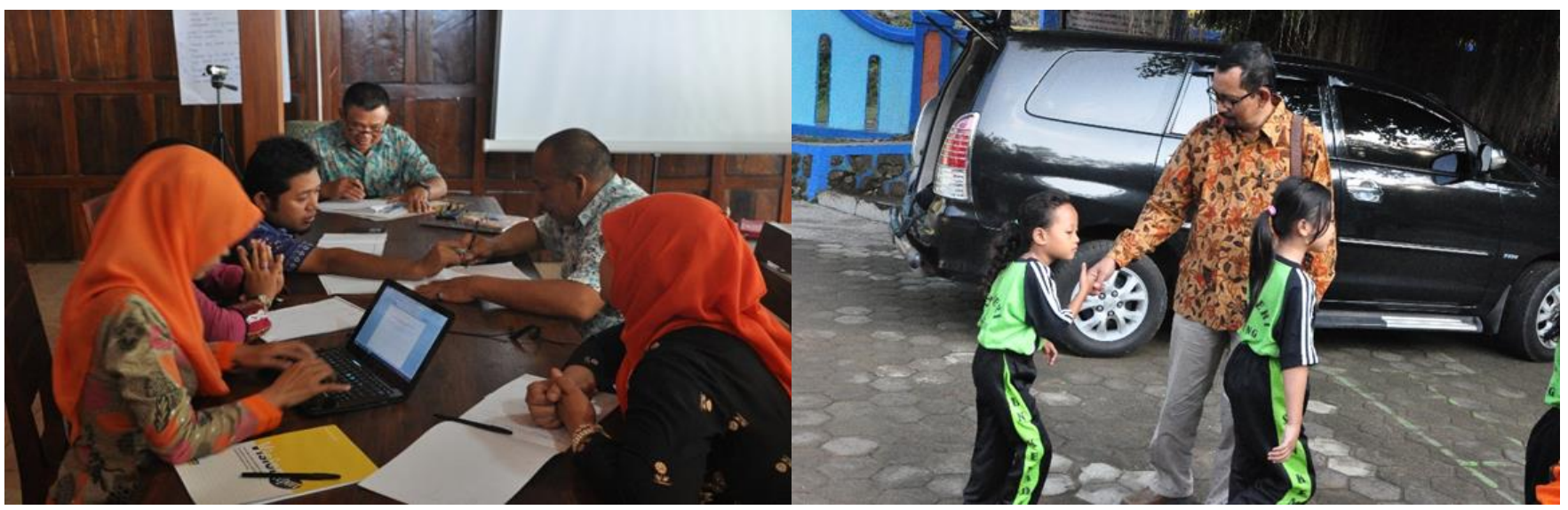

Figure 4. Workshop analysis for child-friendly school policy in Tanjungsari, coastal tourism area

Figure 5. Welcoming student by shaking the hand with the teacher

From Figure 4 above, the results of policy formulation workshop involving actors of policy as stated above, it is decided 7 kinds of school policies (Hajaroh et al., 2017) namely: 1) creating a school environment that is safe from harassment, threats, intimidation, violence, injustice in children; 2) creating a learning community based on local wisdom in the coastal region of Gunungkidul; 3) utilizing science and technology as learning supporter; 4) improving the teachers' competence on learning process in the coastal region of Gunungkidul; 5) increasing the active participation of parents / community; 6) creating comfortable and safe schools conditions; 7) formed a partnership with the community to develop students' potential. This policy is a way for schools in creating child-friendly schools that will be implemented during the first academic year from 2016 to 2017 in three schools. Each school implements to build synergies with the community through parents and the school committee. From the discussions at this late stage, solutions to problems in the form of policies and programs formulated as policy and child-friendly schools' program in three primary schools in coastal areas was chosen.

\section{Aplication of Child-friendly school policy and program}

School started the aplication by organizing the policy through the preparation of programs and school activities. Programs and activities of child-friendly schools are prepared for 1 year. The organization is done by schools by discussions among all components of the school (the principal, teachers, representatives of a society consists of school committees and parents). In these discussions they determine the activities and resources involved in the implementation. Discussions are heldl in a democratic atmosphere; all group members express their opinions.

Seven policies that have been formulated were broken down into programs and activities in schools. Programs and activities made by the school can be classified into two major programs: first, habituation, programs and activities that were carried out every day, every week, or once every two weeks; second, programs and activities that were specifically allocated by the school, incidental performed at a certain time after the agreement between the school and the community / parents, or between the principal and teachers. In this organizing activity, school sets oals, person in charge, costs, sources of funds and carried out from July to November 2016. The person in charge in all programs and activities of child-friendly schools undertaken by all components of the human resources that exist in the schools, the principals, class teachers, stand by teachers, qualified teachers, and parents who are competent in programs or activities. Application of activities in the implementation of policies and programs of child-friendly schools are as follows:

\section{Welcoming the arrival of the child in school}

Welcoming the arrival of the child in school is done from 07.00- 07:15 a.m every morning before class. Teachers waited for the arrival of the children in the school yard, greeted every child who comes to shake their hands, asking how the children are doing especially to children who were absent the day before. These activities every morning showed that the school was welcoming the children who came with their parents. This is consistent with the purpose of child-friendly schools initiated by Unicef. Child-friendly schools are designed to create a welcoming environment so that children can learn (UNICEF, 2009). By the time teacher's welcome children, they also meet the parents who take them to school. This atmosphere cultivated the sense of security for children and felt welcome in the school environment (Figure 5). 


\section{Introducing the rights and obligations of the child}

Children are introduced to their rights and obligations as a child. Rights of the child, among others: right to grow, right to have a name / identity (birth certificate), right to worship according to religion, right to get education, and protection.The rights of children in schools contain every child deserves education, join the learning process, using school facilities, learn comfortably, and get a sense of security (Figure 6).

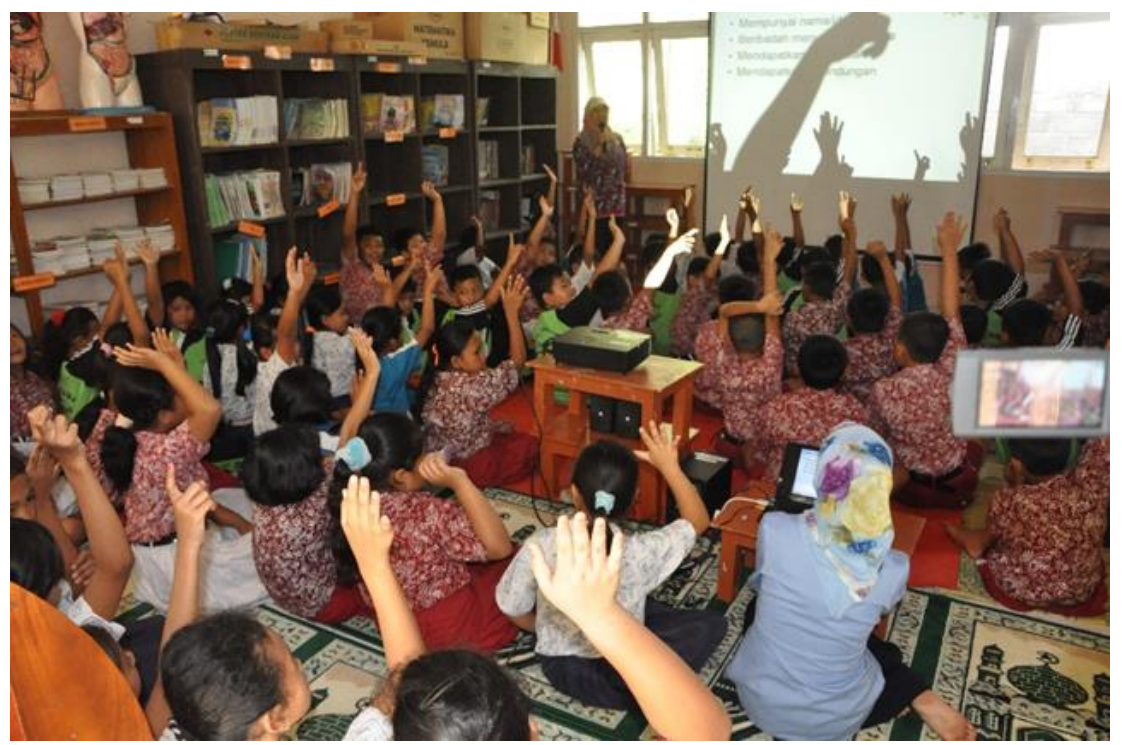

Figure 6. Introducing the right and obligation to student in Kemadang Primary School

The obligation to obey the terms of attendance, school permission mechanism, provision of assessment (academic and morals), and grade provisions. Children enthusiastically participated in this activity can be seen from the dialogue that occurs between the principal with children. According to Miske (2010) the framework for child-friendly schools is to meet the basic rights enshrined in the Convention on the Rights of the Child (CRC), Introduce the rights and obligations to a child is a gift of knowledge and understanding to children but more important than that is the practice of education in schools will fulfill the rights of the child or not. The fulfillment of the children's rights is the purpose of child-friendly schools. This needs to get more attention from schools, parents and the community.

\section{Parenting}

Parenting which is intended in this program is to provide insight to the parents on parenting and education for children of primary school age. These activities provide additional knowledge to parents about the importance of children's education, the importance of synergic coordination and cooperation between schools and parents for educational success purpose. Hardy et al. (2008) examined the relationship between parenting dimensions (involvement, autonomy support and structure) and the internalization of moral values in teenagers. In addition, the positive interaction was found to support autonomy. Through parenting program, parents understand the development and education of their children as well as how to nurture the child will support the education of children so that the parent's policy in education does not conflict with the education policy at schools ( Figure 7).

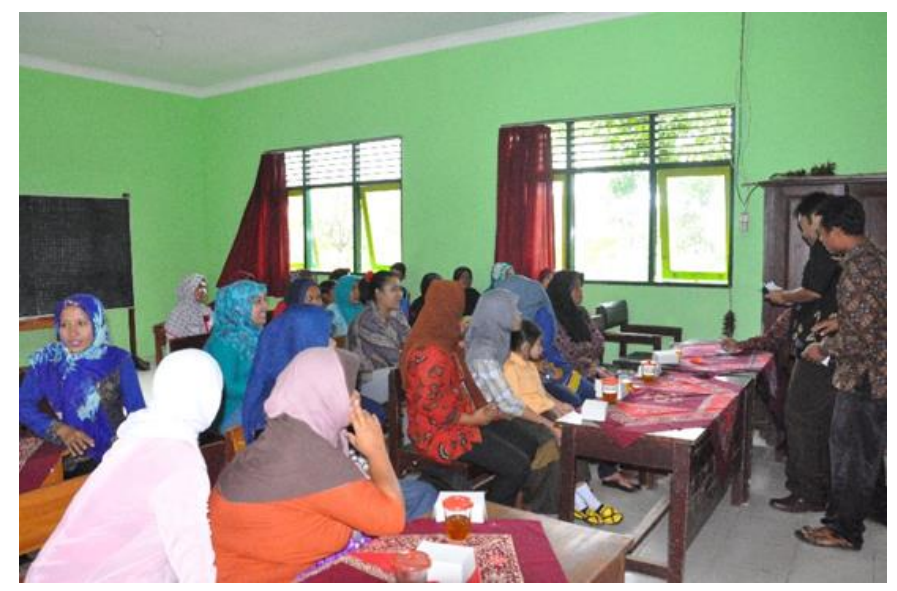

Figure 7. Parenting workshop for parent in the Rejosari Primary School

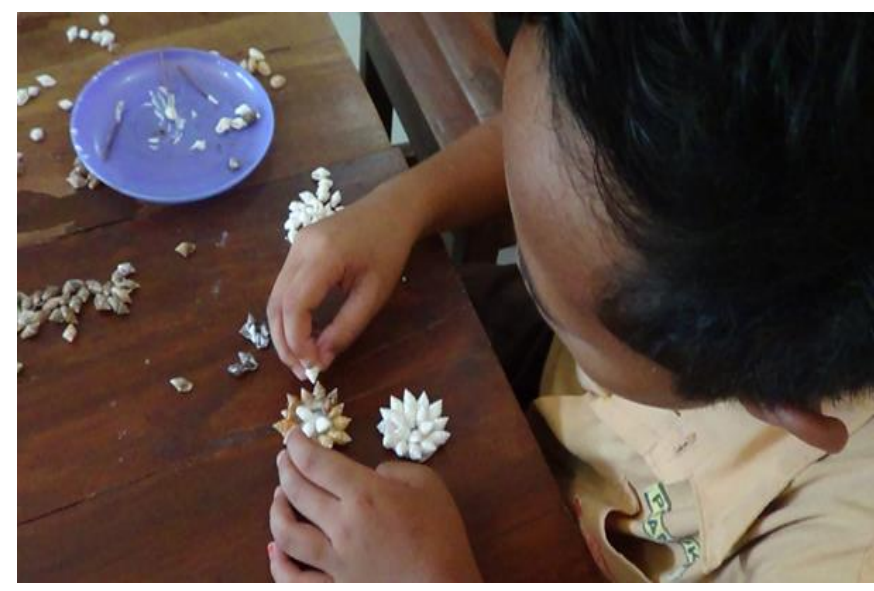

Figure 8. Entrepreneurship Learning in the Rejosari Primary School

\section{Parents / guardians association}

Parents association is an organization of parents of students who are members of the school and certain class. Class association consists of parents from the students from the same class. This association as the place for parents to interact one another and to interact with the class teacher. Communication between parents is done through meetings and through social network 'WhatsApp'. Educational informations are provided by the teacher through this medium such as about the homework, school assignments and other educational information useful for parents. This program is the advanced idea from the parenting program. Real action on the awareness of parents on their children's education and their shared responsibility in forming this association. 


\section{Values Education}

Children in the coastal area have their particular characteristics, especially children in SD Rejosari, they tend to be the kinesthetic type with activities that are not easy to handle. They are also accustomed to move freely and have less concentration to the learning process in the classroom. They always talk with their friends and are joking around, lack of concentration when asked to think or to feel about certain thing. Children need to learn about values repeatedly and continuously performed by the school. Ülavere \& Veisson (2015) states the main scope of value education is to provide support to children's development in a way that enables children to grow into active citizens, and creative, analytical and active individuals. Schools need to build synergies with parents. Values education in schools and give understanding for how important it is to give mentoring for children at home. Values education is done with a holistic, exclusive and inertia- trative approach to the teaching and learning process of Dhunnoo and Adiapen (2013: 123-135). Value-based education in Amollo and Lilian (2017: 194-203) is an important element that influences the moral, ethical, cultural, social and spiritual ideals necessary for the development of children holistically. Giving the value of education at an early age ensures that children are directed by this ideology throughout life. This school needs serious assistance from the authorities to establish safer and more comfortable school for the children and the children will have good manners.

\section{Enterpreneurship Learning}

Environment based enterpreneurship learning by training children to make crafts from shells and other marine animals and how to sell it. Craft skills training is conducted by one of the parents who worked as a beach related craftsman. Children are enthusiastic enough to make turtle shaped key chain and create flower brooch. Children are highly skilled, and it can be seen that each child can make at least one key chain and 2 brooches in less than 60 minutes. At the end of this activity, children collect one set for the assessment and and take the rest to be sold and all the purchased is reported to the teacher (Figure 8).

This learning activity is integrated contextual learning between crafting skill and entrepreneurship skills learning and also it is full of education about values. The values of accuracy, neatness, concentration, perseverance and partnerships were very prominent in this activity. This learning is necessary to proceed with a development on topics that are contextual to the tourist area. There are still many local aspects that can be developed in learning activity including ooking the local food from cassava and fish is done properly.

\section{DISCUSSION}

The implementation of child-friendly school policy as stated in Ministry Policy No. 8 year 2014 through three stages namely: interpretation of policy by developing and formulating school policy; policy decisions; and implementation of policies in schools. The phase of interpretation is the contextualization of school policy. At this stage, it involves all stakeholders such as Gunungkidul education authorities, principals, teachers, community leaders, school committees and parents. The process of formulating the policy formulation is done democratically. It can be seen in two days workshop hat the participants actively participate in the discussions and the policy formulation process. Each individual has a role and idea fit to their capacity. Differences in social and education background did not cause discrimination. The options of the policy and programs were discussed openly and tied to the goal of creating a friendly school for the coastal area chidlren.

Processes in analyzing the policy to formulate child-friendly school policy is based on national policy and is contextual with the coastal tourist district and in line with the concept of policy analysis process stated by Perry (2009), which suggests a conceptual model for analyzing educational policy in a democratic society, based on the key concepts, namely equality, diversity, participation, selection, and cohesion. These five concepts are used as reference in creating the design, evaluation, comparison, and analysis of education policy in a democratic society. The model from Perry also guides the analysis of the link from the five concept and the ways in which these five concepts are complementary each other and mutually contradicted. By providing an integrated view of the five values of democracy, the model can help policy makers and analysts to balance the demands of competing educational policy. Democratic values shared by the school community and the surrounding community help the process of balancing the policy be balanced in determining policy choices and programs.

Three dimensions (people, policies, place) that influence the implementation of the policy as stated by Honig (2006) are also involved in the implementation of child-friendly school policy. People who are involved from the community around the school, education experts, education professionals (teachers) manager of education (school principal) and head of the district education department of Gunungkidul. It's just that in this process, children are no involved as the target of the policy yet. It would be better if in this process the children were involved right from the policy formulation and programming not only as the target of implementation. These three dimensions of implementing the policies always involving people, places and policies that interact as described by Honig as follows Figure 9 below:

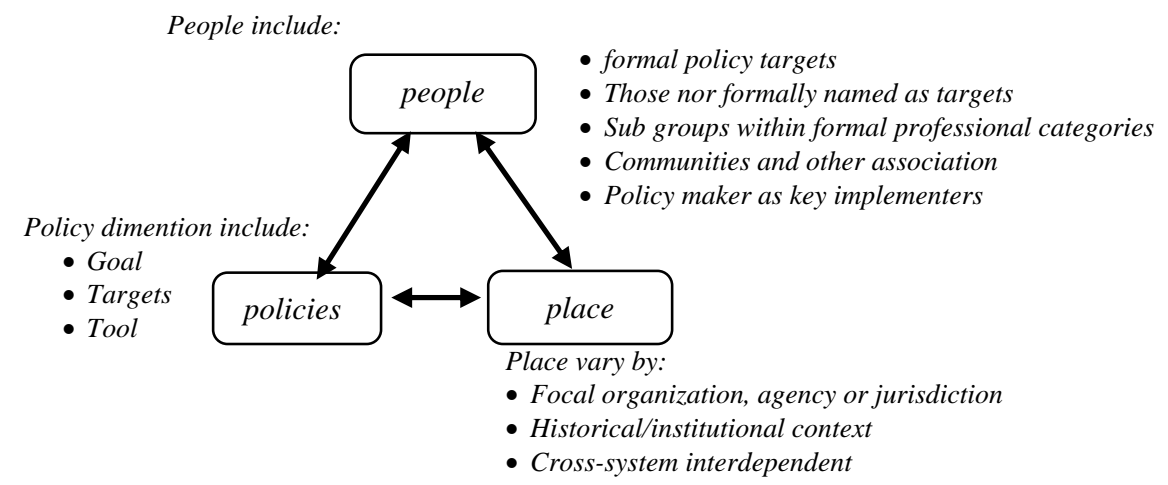

Figure 9. Contemporary Dimensions of Implementing the Policy in Practice and Research (adopted from Honig, 2006)

School as a national policy implementer of Child Friendly School has formulated a policy based on the real issues faced by the communities of coastal area. Therefore the principle of community participation is important to uphold, although according to Akbar et al. (2020) the principles of stakeholder participation in policy planning, including in tourism and education in developing countries are difficult, although the purpose of the plan is generally to develop benefits for local. The real issues faced by communities in coastal tourist attraction area include contextual issues with the change of economy, socio politic, socio culture, science and technology development. Schools along with parents, school committees, community leaders and stakeholders formulate policies based on an issue. This real issue is solved by finding a solution to the various educational policies. The selected education policy is a policy based on the management of the school and 
community. This shows that the dimensions of place influence in implementing the child-friendly school policy, the school policy will vary from one place to another according to the context in which the school is located. Judging from the dimensions of the policy objectives therefore the policy will be different from one school to another depends on the policy issues to be resolved so that the policy targets will be in line with the target of problem solving. Similarly, only with the policy's tool that are needed in the implementation of the policy in accordance with the objectives and targets to be achieved. The three schools that are the subject of this research have the programs that are different focus on the child friendly school policies and program. Parenting is viewed as programs that are required by schools, while the entrepreneurship program becomes the focus in SD kemadang and values education becomes the focus in SD Rejosari.

Policy formulation of child-friendly schools that fit the cultural context of coastal tourist area in Gunungkidul, Yogyakarta within the framework of the implementation of national policies is done through a process of public policy as presented by William Dunn in Subarsono (2006) namely: agenda-setting, policy formulation, adoption of policies, policies implementation and policy assessment. Based on the Dunn concept, the policy process Child-Friendly School policy in Coastal Tourist Area can be described as follows in Figure 10 below:

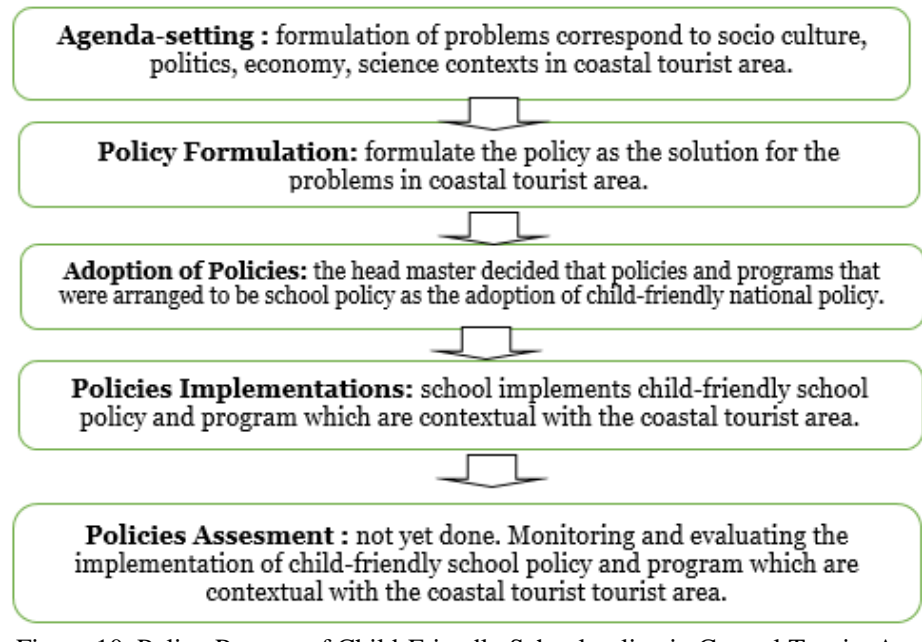

Figure 10. Policy Process of Child-Friendly School policy in Coastal Tourist Area

Child-friendly school policy implementation in coastal tourist areas analyzed with the theory of implementation, it can be said that the implementation of this policy is in line with the theory from Edward III (Tilaar \& Nugroho, 2008). There are four key issues in order to be an effective policy implementation, namely communication, resources, disposition, and bureaucratic structure. The results of the above study also show that the school is able to build the perception among stakeholders that the child-friendly education which is contextual with the coastal tourist area is an urgent matter that should be given solutions to solve them. After that the school and its stakeholders constrain the problem based on the order of the urgency. At the end the school facilitates the support for the issue will be considered as the school agenda. Facilitating the support is done by organizing groups in the society, and the powers owned by the village authorities and the District Education Department. The school ability in moving the school stakeholders using the principles of school-based management. The following table describes the child-friendly school policy implementation in coastal tourist area.

Table 1. Child-friendly School policy implementation in the perspective of Edward III theory

\begin{tabular}{|l|l|}
\hline \multicolumn{1}{|c|}{ Main Issues } & \multicolumn{1}{c|}{ Description } \\
\hline Communication & $\begin{array}{l}\text { Policy is communicated to parents, school committees, stakeholder. Things that were communicated such as about the human } \\
\text { resources involved in the implementation, the source of the funds needed, facilities that support the policy. When things are } \\
\text { being communicated, then the school needs to know the attitude and responses from the parties involved (FGD and } \\
\text { Workshop), and also described the organizational structure associated with policy's implementer. }\end{array}$ \\
\hline Resources & $\begin{array}{l}\text { The resources involved are principals, teachers, students, parents, school committees, stakeholder. Each of these resources } \\
\text { have their own duty and authority. Determination of resources has been made by the school in the hope that the } \\
\text { implementation of the policy can be implemented. }\end{array}$ \\
\hline Dispotition & $\begin{array}{l}\text { The implementer of the policy prepared with a full commitment to implement policies that have been formulated. The school } \\
\text { principal is role model implementer. School principals have a strong commitment, teachers are fully supportive to the } \\
\text { implementation. Students become the subject of child-friendly school. }\end{array}$ \\
\hline Organizational Structure & $\begin{array}{l}\text { The headmaster is the leader of all child-friendly school policy implementation in schools. He/She coordinates with the school } \\
\text { teachers, parents, school committees, students and stakeholders well, so there is no fragmentation in implementation. The } \\
\text { existing obstacles are not related to coordination and cooperation but technical problems, such as blackout. }\end{array}$ \\
\hline
\end{tabular}

The development of child-friendly school policies in coastal areas is part of the development of community-based tourism. The concept of community-based tourism village development according (Arintoko et al., 2020) in general is the concept of development with the tourism sector as a pioneer with priority scale at the village level through community participation in local economic development. Local wisdom-based entrepreneurship education in child-friendly schools is a form of school participation in empowering communities that support tourism development. The tourism sector could have negative and positive impacts on society (Giampiccoli et al., 2020). The role of the community as a provider of the main components of tourism cannot be separated from their basic knowledge of the surrounding environment and its culture (Purnomo et al., 2020). Therefore, education policies that are aligned with tourism in the local community can reduce the negative impact of tourism in Gunawan. Education besides forming character also provides knowledge to students as members of the community. The childfriendly school policy has facilitated children to obtain knowledge relevant to the development of coastal tourism in Gunungkidul.

\section{CONCLUSION}

Schools could move all school stakeholders in developing child-friendly schools. Parents, community leaders, teachers, principals and school supervisor and education authorities have a significant role in the development of child-friendly school in coastal tourism area. 
Considering the environment around the school with the following characteristics: (1) the natural environment is an area prone to earthquakes, especially in case of big earthquake in the coastal areas that can lead to tsunamis (2) economic and cultural conditions of work and employment opportunities. (3) socio cultural conditions. (4) conditions of political culture and power. (5) environmental conditions of communication, Information and Communication Technology.

The participation of parents and the community play an important role in the implementation of policies and programs in the childfriendly school education unit level. In the school-based management requires schools to mobilize the community through active participation in children's education at school. Parents and the community need to work together synergically for the child-friendly school.

\section{REFERENCES}

Amollo, O.P., \& Lilian, G.K. (2017). Teacher Position in Spurring Value Based Education in Early Learning in Nairobi County, Kenya: Addressing Support of Values in School Environment. Journal of Education and Learning, 6(3), 194-203.

Arintoko, A., Ahmad, A.A., Gunawan, D.S., \& Supadi, S. (2020). Community-based tourism village development strategies: A case of Borobudur tourism village area, Indonesia. Geojournal of Tourism and Geosites, 29(2), 398-413. https://doi.org/10.30892/gtg.29202-477

Bøyum, S. (2014). Fairness in education - a normative analysis of OECD policy documents. Journal of Education Policy, 29(6), 856-870. https://doi.org/10.1080/02680939.2014.899396

Çakir, O., Evren, S., Tören, E., \& Kozak, N. (2018). Utilizing the sustainable livelihoods approach to evaluate tourism development from the rural host communities' point of view: The case of Cappadocia (Turkey). Geojournal of Tourism and Geosites, 21(1), 7-25.

Carrington, S., Pillay, H., Tones, M., Nickerson, J., Duke, J., Esibaea, B., \& Fa'asala, C.J. (2017). A case study of culturally informed disability-inclusive education policy development in the Solomon Islands. International Journal of Inclusive Education, 21(5), 495-506. https://doi.org/10.1080/13603116.2016.1218952

Clair, N., Miske, S., \& Patel, D. (2012). Child Rights and Quality Education. European Education, 44(2), 5-22. https://doi.org/10.2753/eue1056-4934440201

Convention on the Rights of the Child. (1990). Convention on the Rights of the Child Adopted and opened for signature, ratification and accession by General Assembly resolution. 44/25 of 20 November 1989 entry into force 2 September 1990, in accordance with article 49.

Cross, D., Monks, H., Hall, M., Shaw, T., Pintabona, Y., Erceg, E., \& Lester, L. (2011). Three-year results of the friendly schools whole-of-school intervention on children's bullying behaviour. British Educational Research Journal, 37(1), 105-129. https://doi.org/10.1080/01411920903420024

Dhunnoo, S., \& Adiapen, V. (2013). Value-based education and teacher education in Mauritius: Analysing the pertinence of value-based education at school to reconstruct society. Purushartha, 6(1), 123-135.

Fast, I. (2016). Understanding Educational Policy Formation. Sociology of Education, 89(1), 59-78. https://doi.org/10.1177/0038040715615923

Giampiccoli, A., Abdul Muhsin, B., \& Mtapuri, O. (2020). Community-Based Tourism in the Case of the Maldives. GeoJournal of Tourism \& Geosites, 29(2), 428-439. https://doi.org/10.30892/Gtg.29204-479

Hajaroh, M., Rukiyati, Andriani, L., \& Saptono, B. (2017). Analisis Kebijakan Sekolah Ramah Anak di Kawasan Pesisir Wisata. Yogyakarta: Andi Ofset.

Hardy, S.A., Padilla-Walker, L.M., \& Carlo, G. (2008). Parenting dimensions and adolescents' internalisation of moral values. Journal of Moral Education, 37(2), 205-223. https://doi.org/10.1080/03057240802009512

Honig, M.I. (2006). New Directions in Education Policy Implementation: Confronting Complexity. New York: State University of New York Press.

Miles, M.B., \& Huberman, A.M. (1992). Qualitative Data Analysis: A Sourcebook of New Method. United States of America: Sage Publications, Inc.

Miske, S.J. (2010). Child-Friendly Schools - Safe Schools. In Second International Symposium on Children at Risk and in Need of Protection. Turkey.

Morrison, K. (1996). Developing a whole-school behaviour policy in primary schools. An International Journal of Personal, Social and Emotional Development, 14(1).

Perry, L.B. (2009). Conceptualizing Education Policy in Democratic Societies. Journal Educational Policy, 23(3), $423-450$.

Perryman, J., Ball, S.J., Braun, A., \& Maguire, M. (2017). Translating policy: governmentality and the reflective teacher. Journal of Education Policy, 32(6), 745-756. https://doi.org/10.1080/02680939.2017.1309072

Purnomo, A., Idris, I., \& Kurniawan, B. (2020). Understanding local community in managing sustainable tourism at Baluran National Park - Indonesia. Geojournal of Tourism and Geosites, 29(2), 508-520. https://doi.org/10.30892/gtg.29210-485

Samara, M., \& Smith, P.K. (2008). How schools tackle bullying, and the use of whole school policies: changes over the last decade. International Journal of Experimental Educational Psychology, 28, 663-676.

Setyawan, D. (2015). Pelaku Kekerasan Terhadap Anak Tiap Tahun Meningkat. Retrieved from http://www.kpai.go.id

Thiagarajan, \& Semmel, D.S. (1974). Instructional Development for Training Teachers of Expectional Children. Minnesota: Leadership Training Institute/ Special Education, University of Minnesota.

Tilaar, \& Nugroho, R. (2008). Kebijakan Pendidikan. Yogyakarta: Pustaka Pelajar.

Tuytens, M., \& Devos, G. (2014). The problematic implementation of teacher evaluation policy: School failure or governmental pitfall? Educational Management Administration \& Leadership, 42(4), 155-174.

Tuzunkan, D. (2018). Undergraduate Tourism Students' Perceptions and Attitudes Towards Tourism Industry: The Case of Daejeon, South Korea. Geojournal of Tourism and Geosites, 21(1), 103-111.

Ülavere, P., \& Veisson, M. (2015). Values and Values Education in Estonian Preschool Child Care Institutions. Journal of Teacher Education for Sustainability. https://doi.org/10.1515/jtes-2015-0014

Van der Sluis, M.E., Reezigt, G. J., \& Borghans, L. (2017). Implementing New Public Management in Educational Policy. Educational Policy, 31(3), 303329. https://doi.org/10.1177/0895904815598393

Vincent, C., Neal, S., \& Iqbal, H. (2016). Children's friendships in diverse primary schools: teachers and the processes of policy enactment. Journal of Education Policy, 31(4), 482-494. https://doi.org/10.1080/02680939.2015.1130859

Young, T., \& Lewis. (2015). Educational Policy Implementation Revisited. Educational Policy, 29(1), 3-17.

*** KPAI. (2013). Undang - Undang (UU) RI No.23 Tahun 2002 Tentang Perlindungan Anak. Retrieved from https://www.kpai.go.id/hukum/undangundang-uu-ri-no-23-tahun-2002-tentang-perlindungan-anak.

*** Republic Indonesia. (2014). Peraturan Menteri Pemberdayaan Perempuan dan perlindungan Anak nomor 14 tahun 2014 tentang Sekolah Ramah Anak.

*** UNICEF. (2006). Child Friendly School Manual. New York. Retrieved from https://www.unicef.org/publications/files/Child_Friendly_Schools_Manual_ EN_040809.pdf

*** UNICEF. (2009). Child Friendly School Programming (Global Evaluation Report). 